\title{
Productive Performance of Flame Seedless Grapevines in Relation to Application of Rocket Oil
}

\author{
M. A. Hussein* and H. M. Alam** \\ *Horticulture. Department, Faculty of Agriculture, Souhag University, Souhag and \\ "Viticulture, Department, Horticulture Research Institute, Agriculture Research \\ Centre, Cairo, Egypt.
}

$\mathbf{T}$

HIS STUDY was carried out during two successive 2016 and 2017 experimental seasons on Flame seedless grapevine grown in private vineyard located in Sohag Governorate, Egypt. It's were carefully selected as being healthy vines, uniform as possible in their vigour and size to study the effect of foliar spray with rocket oil. Flame seedless is one of the most popular different cultivars of table grapes in Egypt, is dependent upon its desirable appearance. Improving the growth and productivity of this crop by many ways i.e. fertilization, plant hormone, and plant extracts spray application. Flame seedless grapevine treated one, two or three sprays of rocket oil at $0.0125,0.025,0.05$ and $0.1 \%$ ( at the beginning of growth, before bloom and after bloom). Growths, nutritional status, yield and berries qualities in response to rocket oil treatments were investigated. Using rocket oil once, twice or three times at 0.0125 to $0.1 \%$ effectively enhanced main shoot length, leaf surface area, leaf mineral content $(\mathrm{N}$, P\& K), yield as well as physical and chemical characteristics of berries comparing with the control treatment. Improving on these parameters were increased when increasing rocket oil concentrations and number of times spray. Performing three sprays with rocket oil at $0.1 \%$ gave the highest values with regard to yield and fruit quality of Flame seedless grapevines.

Keywords: Flame seedless Grapevine, Rocket oil, main Shoot length, Leaf area, Quality, Yield.

\section{Introduction}

Grape vine (Vitis vinifera L.) is considered one of the most popular and common fruits in the world. Newly increased area of grapevines in Egypt reached 192934 fed. Which produce 1596169 tons (according to the latest statistics of the ministry of agriculture (2014). The market value of grape for Flame seedless, which is one of the most popular different cultivars of table grapes in Egypt, is dependent upon its desirable appearance and berries quality. Grapes are highly perishable non-climacteric fruits and, their fruit quality characteristics are influenced by many factors as, temperature, nutrition and irrigation. Used some bio material such as plant extract could be used to improve yield and fruit quality.

Plant extracts application improve growth and productivity of fruit crops by regulating plant growth and relieving biotic and abiotic stresses was applied by many researchers (Culver et al., 2012 and Srivastava \& Lal, 1997). Stated that spraying neem extracts three times was accompanied with controlling anthracnose of Taimour mango trees (Chowdhury et al., 2007). Spraying Keitte mango trees four times with fenugreek seed sprout extractand/ or rocket seed sprout extract each at 0.5 to $4 \%$ promote all growth characters, nutritional status of trees, yield and physical and chemical properties of fruits (Mahmoud, 2014). Ruby seedless grapevines yield was significantly increased after spraying with roselle, while turmeric extract was effective in improving the yield and fruit quality of Thompson seedless grapevines (Armanious, 2014 and Gad El- Kareem \& Abd El- Rahman, 2013). The rocket oil contains mainly fatty acids, oleic, linoleic, linolenic and aerosic. Unsaturated fatty acids constitute $85.1-89.1 \%$ of the total fat. It also contains volatile oils (Flanders and Abdulkarim, 1995). In addition, the seeds of rocket contain calcium, iron, magnesium, potassium, sulfur, sodium, phosphorus and iodine, as well as being rich in carotene and vitamins such as vitamin $\mathrm{E}$, $\mathrm{C}, \mathrm{K}$, and most types of vitamin B group such as (B1), (B2), (B6) and (B12) (Carr et al., 2004). 
The objective of this study was found the best concentration and number of time application of rocket oil to improve growth, fruiting and quality characteristics of Flame seedless grapevines.

\section{Materials and Methods}

This study was carried out during two successive 2016 and 2017 experimental seasons on 78 uniform in vigour10- years old Flame seedless grapevines (not grafted)., trained to head pruning and planted at $2 \times 2.5 \mathrm{~m}$ apart in a clay soil under surface irrigation system were carefully selected as being healthy, grown in private vineyard located in Sohag Governorate, Egypt. To study the effect of foliar spray with rocket oil. Regularly the same horticultural practices (fertilization, irrigation pruning etc., ) adopted in Flame seedless orchards of the region.

This experiment included the following thirteen treatments:

- Control (unsprayed with rocket oil).

- $\quad$ Spraying rocket oil once at $0.0125 \%$.

- $\quad$ Spraying rocket oil once at $0.025 \%$.

- $\quad$ Spraying rocket oil once at $0.05 \%$.

- $\quad$ Spraying rocket oil once at $0.1 \%$.

- $\quad$ Spraying rocket oil twice at $0.0125 \%$.

- $\quad$ Spraying rocket oil twice at $0.025 \%$.

- $\quad$ Spraying rocket oil twice at $0.05 \%$.

- $\quad$ Spraying rocket oil twice at $0.1 \%$.

- $\quad$ Spraying rocket oil thrice at $0.0125 \%$.

- $\quad$ Spraying rocket oil thrice at $0.025 \%$.

- $\quad$ Spraying rocket oil thrice at $0.05 \%$.

- $\quad$ Spraying rocket oil thrice at $0.1 \%$.

Vines sprayed once: at the beginning of growth. Vines sprayed twice: first at the beginning of growth and the second before bloom.

Vines sprayed thrice: first at the beginning of growth, the second before bloom and the third after bloom.

The complete randomized block design with three replications (each replicate was represented by two vines) was used for arranging the previously mentioned thirteen spray treatments.

\footnotetext{
Vegetative growth

Leaf surface area/ vine $\left(\mathrm{m}^{2}\right)$ was recorded in the all leaves per vine at harvest time(Last week of May) according to the following equation that was outlined by Ahmed and Morsy (1999) where twenty leaves / replicate were picked at Veraison of the apical $6^{\text {th }}$ and $7^{\text {th }}$ leaves. La $=0.40(0.79 \times$ $\left.\mathrm{W}^{2}\right)+15.33$.
}

Leaf surface area $=$ Average La $\mathrm{x}$ Number of leaves/vine.

Average length of the main shoot (cm): Length of main shoot was measured at last week of May.

Leaf content: Leaf content of nitrogen, phosphorus and potassium were determined in the oven dried leaf samples (At full bloom, samples of 20 leaf petioles per each replicate were taken from leaves opposite to cluster were used for the determination of $\mathrm{N}, \mathrm{P}$ and $\mathrm{K}$ ). Nitrogen (\%) was determined by the modified Micro-kejldahl method as described by Wilde et al. (1985). Phosphorus (\%) was determined by using Olsen method as reported by Chapman and Pratt (1965). Potassium (\%) was flame photometrically determined using the method outlined by Chapman and Pratt, (1965).

Yield as well as physical and chemical properties of the berries: At harvest when the total soluble solids/ acid index reached 24- 25: 1 according to Weaver (1976). The clusters were harvested and the following aspects were estimated.

- $\quad 1$-Average number of cluster per vine.

- 2-Average of cluster weight (g).

- $\quad 3$-Yield / vine (Kg) was calculated from average number of cluster per vine and average cluster weight $(\mathrm{g})$.

- 4-Averagesof length and width of cluster $(\mathrm{cm})$.

- 5-Average weight of 100 berry (g).

- 6-Averages height and diameter of berry $(\mathrm{cm})$.

- 7-Percentage of total soluble solids in the berry juice was determined by the use of Galilio hand refractometer.

- Percentage of total acidity in the juice was determined by titration with a known normality of sodium hydroxide solution $(0.1 \mathrm{~N})$ and using phenolphthalein as an indicator then the results were calculated as grams of tartaric acid / $100 \mathrm{~g}$ grams of juice according to the Association of Official Agricultural Chemists (A.O.A.C., 1995).

- The ratio between total soluble solids and total acidity was calculated. Data were statistically analyzed using standard methods according Mead et al. (1993) and new L.S.D. test was used for comparing between treatment means. 


\section{Results}

Data in Table 1 showed the effect of different concentrations and frequencies of rocket oil spraying on leaf surface area /vine $\left(\mathrm{m}^{2}\right)$, main shoot length and leaf mineral content of Flame seedless grapevine during 2016 and 2017 seasons: Leaf area and shoot length: All treatments recorded higher significant leaf surface area and main shoot length values than control. There was a gradual stimulation on these growth characters with increasing concentrations from 0.0125 to $0.1 \%$ and frequencies of rocket oil from once to thrice times. Therefore, the maximum values of these growth characters were observed with rocket oil at $0.1 \%$ thrice. The minimum values were recorded on untreated vine. These results were true during both seasons.

Leaf mineral content: Percentages of N, P and $\mathrm{K}$ in the leaves significantly stimulated in response to spraying rocket oil once, twice or thrice times at 0.0125 to $0.1 \%$ rather than non- application. The present treatments had no significant for leaf content of phosphorus\% in second season only. While, control treatment had the lowest content of nitrogen, phosphorus and potassium than the others treatments. The maximum values of leaf mineral content were observed with rocket oil at $0.1 \%$ thrice times, it recorded 2.41 and $2.50 \%$ for nitrogen content, 0.35 and $0.38 \%$ in first season for phosphorus content and $1.63 \%$ for potassium content in the two seasons, respectively. The minimum values were observed on untreated vine it recorded 1.61 and $1.62 \%$ for nitrogen content, 0.13 and $0.15 \%$ for phosphorus content and 1.18 and $1.14 \%$ for potassium content in the two seasons, respectively.

Data in Table 2 showed the effect of different concentrations and frequencies of rocket oil spraying on number of clusters per vine, average cluster weigh, yield per vine and cluster length and width of Flame seedless grapevine during 2016 and 2017 seasons:

Number of clusters per vine: A positive relationship was found obviously between spraying of rocket oil and number of clusters per vine in the first season of the experiment, but in the second season had no significant on number of clusters per vine. Consequently, the vine received once spray at 0.0125 in the first season gave the lowest significant value in this respect; it presented 24 cluster/vine. Reversely, vines sprayed with rocket oil at $0.1 \%$ three times showed the highest significant effect for this parameter; it presented 33 cluster/vine.

Cluster weight: Regard to the effect on average cluster weight, vines treated with rocket oil at $0.1 \%$ in the first season and rocket oil at $0.025 \%$ three times in the second season gave the highest average cluster weight compare all treatments $465 \& 445$. While, control treatment gave a lower average cluster weight than the other treatment; hence, it presented 354.3 and $355 \mathrm{~g}$ in the two seasons, respectively.

Yield per vine: It is clear from the obtained data that rocket oil at 0.0125 to $0.1 \%$ once, twice or thrice times significantly improved the yield per vine (except Rocket oil at $0.0125 \%$ once in both seasons) as compared to the control treatment. There was a gradual reduction of the yield with increasing rocket oil frequencies from once to thrice times. The maximum yield per vine (15.27 and $15.89 \mathrm{~kg} /$ vine) was observed on the vine that received three sprays of rocket oil at $0.1 \%$ three times in the two seasons respectively. The lowest value was recorded on the vine received once spray at 0.0125 in the first season, in the second season observed on untreated vine. These results were true during both seasons.

Cluster length and width: These parameters were significantly affected by all different spraying applications of rocket oil during both seasons. In particular, spraying rocket oil at $0.1 \%$ three times presented highest cluster length and width compared with the other treatments. Then, it recorded 20.73 and 21.86 $\mathrm{cm}$ for cluster length and 14.03 and $14.43 \mathrm{~cm}$ for cluster width in both seasons, respectively. Control treatment gave the lowest cluster length and width; therefore, it recorded 16.16 and $16.30 \mathrm{~cm}$ for cluster length and 10.63 and $10.76 \mathrm{~cm}$ for cluster width in both seasons, respectively. 
TABLE 1. Effect of different concentrations and frequencies of rocket oil spraying on leaf area /vine (cm2), main shoot length and leaf mineral content of Flame seedless grapevine during 2016 and 2017 seasons.

\begin{tabular}{|c|c|c|c|c|c|c|c|c|c|c|}
\hline \multirow[t]{2}{*}{ Treatments } & \multicolumn{2}{|c|}{$\begin{array}{l}\text { leaf surface } \\
\text { area }(\mathrm{m} 2)\end{array}$} & \multicolumn{2}{|c|}{$\begin{array}{l}\text { Main shoot } \\
\text { length(cm) }\end{array}$} & \multicolumn{2}{|c|}{ Leaf N \% } & \multicolumn{2}{|c|}{ Leaf P \% } & \multicolumn{2}{|c|}{ Leaf K \% } \\
\hline & 2016 & 2017 & 2016 & 2017 & 2016 & 2017 & 2016 & 2017 & 2016 & 2017 \\
\hline Control & 16.10 & 17.4 & 120.00 & 129.33 & 1.61 & 1.62 & 0.13 & 0.153 & 1.18 & 1.14 \\
\hline Rocket oil at $0.0125 \%$ once & 16.06 & 19.33 & 125.00 & 134.66 & 1.69 & 1.68 & 0.17 & 0.180 & 1.29 & 1.21 \\
\hline Rocket oil at $0.025 \%$ once & 17.03 & 19.00 & 126.33 & 138.00 & 1.69 & 1.69 & 0.20 & 0.220 & 1.30 & 1.30 \\
\hline Rocket oil at $0.05 \%$ once & 19.10 & 19.83 & 129.00 & 136.66 & 1.70 & 1.69 & 0.23 & 0.253 & 1.41 & 1.41 \\
\hline Rocket oil at $0.1 \%$ once & 21.66 & 21.10 & 132.00 & 140.33 & 1.72 & 1.74 & 0.26 & 0.257 & 1.38 & 1.38 \\
\hline Rocket oil at $0.0125 \%$ twice & 19.16 & 20.26 & 131.00 & 138.66 & 1.73 & 1.69 & 0.26 & 0.283 & 1.44 & 1.44 \\
\hline Rocket oil at $0.025 \%$ twice & 16.80 & 20.33 & 133.00 & 139.00 & 1.84 & 1.82 & 0.27 & 0.283 & 1.47 & 1.47 \\
\hline Rocket oil at $0.05 \%$ twice & 18.66 & 19.10 & 134.66 & 141.33 & 1.90 & 1.80 & 0.29 & 0.290 & 1.42 & 1.42 \\
\hline Rocket oil at $0.1 \%$ twice & 21.36 & 19.20 & 139.33 & 152.00 & 1.98 & 1.99 & 0.30 & 0.313 & 1.45 & 1.45 \\
\hline Rocket oil at $0.0125 \%$ thrice & 21.93 & 20.16 & 144.00 & 158.66 & 2.11 & 2.08 & 0.30 & 1.217 & 1.49 & 1.49 \\
\hline Rocket oil at $0.025 \%$ thrice & 20.10 & 21.03 & 142.66 & 165.66 & 2.21 & 2.28 & 0.32 & 0.337 & 1.56 & 1.56 \\
\hline Rocket oil at $0.05 \%$ thrice & 22.30 & 21.86 & 138.00 & 167.00 & 2.22 & 2.20 & 0.33 & 0.323 & 1.70 & 1.70 \\
\hline Rocket oil at $0.1 \%$ thrice & 23.00 & 22.53 & 157.33 & 165.33 & 2.41 & 2.50 & 0.35 & 0.380 & 1.63 & 1.63 \\
\hline New L.S.D. at 5\% & 1.01 & 1.62 & 4.85 & 5.30 & 0.08 & 0.06 & 0.02 & N.S & 0.10 & 0.06 \\
\hline
\end{tabular}

TABLE 2. Effect of different concentrations and frequencies of rocket oil spraying on yield per vine, number of clusters per vine, average cluster weigh and cluster length and width of Flame seedless grapevine during 2016 and 2017 seasons.

\begin{tabular}{|c|c|c|c|c|c|c|c|c|c|c|}
\hline \multirow{2}{*}{ Treatments } & \multicolumn{2}{|c|}{ No. of cluster/vine } & \multicolumn{2}{|c|}{$\begin{array}{c}\text { Cluster weight } \\
\text { (gm) }\end{array}$} & \multicolumn{2}{|c|}{ Yield/vine (kg) } & \multicolumn{2}{|c|}{$\begin{array}{l}\text { Cluster length } \\
(\mathbf{c m})\end{array}$} & \multicolumn{2}{|c|}{$\begin{array}{l}\text { Cluster width } \\
(\mathrm{cm})\end{array}$} \\
\hline & 2016 & 2017 & 2016 & 2017 & 2016 & 2017 & 2016 & 2017 & 2016 & 2017 \\
\hline Control & 24.66 & 26.33 & 354.3 & 355.0 & 8.74 & 9.330 & 16.16 & 16.30 & 10.63 & 10.76 \\
\hline Rocket oil at $0.0125 \%$ once & 24.00 & 26.00 & 361.6 & 383.3 & 8.67 & 9.960 & 17.20 & 17.46 & 11.33 & 11.53 \\
\hline Rocket oil at $0.05 \%$ once & 28.66 & 30.33 & 391.6 & 391.6 & 11.21 & 11.877 & 18.43 & 18.93 & 12.20 & 13.33 \\
\hline Rocket oil at $0.1 \%$ once & 27.66 & 30.66 & 378.3 & 408.3 & 10.43 & 12.500 & 18.83 & 18.93 & 13.00 & 13.13 \\
\hline Rocket oil at $0.0125 \%$ twice & 30.66 & 31.66 & 408.3 & 404.3 & 12.54 & 12.817 & 19.16 & 18.63 & 13.50 & 13.10 \\
\hline Rocket oil at $0.1 \%$ twice & 28.66 & 33.66 & 423.3 & 411.6 & 12.12 & 13.893 & 20.16 & 20.70 & 14.10 & 14.00 \\
\hline Rocket oil at $0.0125 \%$ thrice & 26.00 & 32.00 & 436.6 & 406.6 & 11.41 & 13.057 & 19.80 & 18.53 & 13.96 & 13.53 \\
\hline Rocket oil at $0.025 \%$ thrice & 27.33 & 31.00 & 428.3 & 445.0 & 11.68 & 13.757 & 19.70 & 18.86 & 13.36 & 13.53 \\
\hline Rocket oil at $0.05 \%$ thrice & 30.33 & 32.33 & 445.0 & 430.0 & 13.51 & 13.837 & 20.63 & 20.40 & 14.00 & 14.06 \\
\hline Rocket oil at $0.1 \%$ thrice & 33.00 & 37.66 & 465.0 & 421.6 & 15.27 & 15.887 & 20.73 & 21.86 & 14.03 & 14.43 \\
\hline New L.S.D. at $5 \%$ & 5.67 & N.S & 14.82 & 24.01 & 1.71 & 1.65 & 0.85 & 1.02 & 0.49 & 0.44 \\
\hline
\end{tabular}

Egypt. J. Hort. Vol. 44, No.2 (2017) 
Data in Table 3 showed effect of different concentrations and frequencies of rocket oil spraying on some berry physical and chemical properties of Flame seedless grapevine during 2016 and 2017 seasons:

Weight of 100 berry, berry height and diameter: Different concentrations and number of spraying time of rocket oil significantly affected on 100 berries weight and both berry height and diameter of Flame seedless grapes. The highest values of 100 berries weight and both berry height and diameter were obtained from vines spraying rocket oil at $0.1 \%$ three times followed by vine spraying with rocket oil at $0.05 \%$ three times, respectively. On the other hand, control treatment induced lower values in this respect during both seasons.

TSS, acidity and TSS/acid ratio: TSS\% obvious that vines spraying with rocket oil at $0.1 \%$ three times significantly increased the value of TSS percentage compared with the other treatments followed by vine spraying rocket oil at $0.05 \%$ three times in first season only of the experiment. The data also revealed that control treatment presented the lowest value of TSS. Regard to the effect of different treatments on titratable acidity, data reverted that titratable acidity gave an adverse trend to that noticed with soluble solids content. Consequently, vines spraying with rocket oil at $0.1 \%$ three times showed a lower titratable acidity in berry juice in comparison with the others. On the other hand, control treatment occurred in a higher titratable acidity in berry juice compared to allthe other treatments during both seasons. Finally, the values of TSS/ acid ratio gave a similar trend to that noticed with the percentages of soluble solids content; therefore vines spraying with rocket oil at $0.1 \%$ three times gave a higher TSS/acid ratio than all the other treatment. While, control treatment showed a lower value of TSS/acid ratio than all the others during two seasons of the study.

TABLE 3. Effect of different concentrations and frequencies of rocket oil spraying on some berry physical and chemical properties of Flame seedless grapevine during 2016 and 2017 seasons.

\begin{tabular}{|c|c|c|c|c|c|c|c|c|c|c|c|c|}
\hline \multirow[t]{2}{*}{ Treatments } & \multicolumn{2}{|c|}{$\begin{array}{c}\text { Weight of } \\
100 \text { berry (g) }\end{array}$} & \multicolumn{2}{|c|}{$\begin{array}{r}\text { Berry } \\
\text { diameter }\end{array}$} & \multicolumn{2}{|c|}{ berry height } & \multicolumn{2}{|c|}{ T.S.S \% } & \multicolumn{2}{|c|}{$\begin{array}{c}\text { Total acidity } \\
\%\end{array}$} & \multicolumn{2}{|c|}{$\begin{array}{l}\text { T.S.S /acid } \\
\text { ratio }\end{array}$} \\
\hline & 2016 & 2017 & 2016 & 2017 & 2016 & 2017 & 2016 & 2017 & 2016 & 2017 & 2016 & 2017 \\
\hline Control & 249.00 & 260.00 & 1.11 & 1.10 & 1.40 & 1.37 & 18.00 & 17.93 & 0.717 & 0.730 & 25.08 & 25.0 \\
\hline Rocket oil at $0.0125 \%$ once & 273.67 & 285.66 & 1.19 & 1.18 & 1.51 & 1.48 & 18.66 & 18.60 & 0.653 & 0.650 & 28.73 & 28.73 \\
\hline Rocket oil at $0.025 \%$ once & 280.00 & 291.66 & 1.21 & 1.18 & 1.52 & 1.51 & 19.33 & 19.06 & 0.610 & 0.620 & 31.20 & 31.20 \\
\hline Rocket oil at $0.05 \%$ once & 282.00 & 285.00 & 1.27 & 1.27 & 1.58 & 1.58 & 19.66 & 19.20 & 0.617 & 0.630 & 31.16 & 31.16 \\
\hline Rocket oil at $0.1 \%$ once & 289.67 & 307.33 & 1.30 & 1.27 & 1.59 & 1.59 & 19.26 & 19.00 & 0.603 & 0.597 & 32.33 & 31.40 \\
\hline Rocket oil at $0.0125 \%$ twice & 280.67 & 296.66 & 1.35 & 1.33 & 1.68 & 1.70 & 19.23 & 18.80 & 0.613 & 0.620 & 30.96 & 30.80 \\
\hline Rocket oil at $0.025 \%$ twice & 298.33 & 310.00 & 1.26 & 1.26 & 1.49 & 1.28 & 18.96 & 18.93 & 0.613 & 0.610 & 31.13 & 30.90 \\
\hline Rocket oil at $0.05 \%$ twice & 296.67 & 310.66 & 1.21 & 1.30 & 1.52 & 1.65 & 19.13 & 19.03 & 0.597 & 0.603 & 31.76 & 32.00 \\
\hline Rocket oil at $0.1 \%$ twice & 301.00 & 317.33 & 1.40 & 1.36 & 1.69 & 1.71 & 19.20 & 19.06 & 0.603 & 0.620 & 31.03 & 31.66 \\
\hline Rocket oil at $0.0125 \%$ thrice & 312.00 & 310.00 & 1.22 & 1.23 & 1.55 & 1.59 & 19.63 & 19.43 & 0.613 & 0.623 & 31.46 & 31.63 \\
\hline Rocket oil at $0.025 \%$ thrice & 315.00 & 366.66 & 1.26 & 1.29 & 1.57 & 1.60 & 20.16 & 20.16 & 0.580 & 0.610 & 33.20 & 34.83 \\
\hline Rocket oil at $0.05 \%$ thrice & 330.0 & 373.33 & 1.32 & 1.35 & 1.70 & 1.70 & 20.50 & 20.00 & 0.573 & 0.590 & 34.76 & 34.80 \\
\hline Rocket oil at $0.1 \%$ thrice & 365.00 & 388.33 & 1.40 & 1.41 & 1.73 & 1.76 & 21.06 & 20.73 & 0.567 & 0.563 & 37.56 & 36.70 \\
\hline New L.S.D. at $5 \%$ & 24.00 & 22.89 & 0.08 & 0.06 & 0.10 & 0.10 & 0.40 & 0.55 & 0.02 & 0.02 & 1.42 & 1.24 \\
\hline
\end{tabular}




\section{Discussion}

The rocket oil contains of mainly fatty acids, oleic, linoleic and aerosic. Unsaturated fatty acids constitute $85.1-89.1 \%$ of the total fat. It also contains volatile oils (Flanders and Abdulkarim, 1995). In addition, the seeds of rocket contain of calcium, iron, magnesium, potassium, sulfur, sodium, phosphorus and iodine, as well as being rich in carotene and vitamins such as vitamin $\mathrm{E}$, $\mathrm{C}, \mathrm{K}$, and most types of vitamin $\mathrm{B}$ group such as (B1), (B2), (B6) and (B12) (Carr et al., 2004). The promoting effect of rocket oil on growth and yield of flame seedless grapevines might be attributed to its higher own content from vitamins and some nutrients, volatile, oils and flavonoids, that act as antioxidants protecting plant cells from death and enhancing cell division and the biosynthesis of organic foods These results regarding the beneficial effects of plant extracts on growth and fruiting of fruit crops are in agreement with those obtained by Gad El-Kareem \& Abd El-Rahman (2013), Abd El-Rahman \& El-Masry (2012), Abdel-al \& Aly (2013) and Ahmed et al. (2013).

\section{Conclusion}

From the above results, it could be concluded that, using rocket oil at $0.1 \%$ three times had obvious effect on vegetative growth, leaves mineral content, yield and fruit quality of flame seedless grapevines. Therefore, rocket seed oil can be safety recommended as a nature bio stimulates to be used effectively by farmers for improving most desirable measurements of flame seedless grapevines grown under the same experimental conditions.

Acknowledgements: The authors are thankful to Sohag University, Horticulture Department for financing the project to conduct the present study.

Funding statements: The authors received no external funding for this study

Conflicts of interest: no conflicts of interest to declare

\section{Reference}

Abd El-Rahman, M.A.M. and El- Masry S.M.A. (2012) Response of Valencia orange trees to foliar application of some vitamins, salicylic acid and turmeric extract. Minia J. Agric. Res. develop., 5 (32), 1-17.
Abdel-al, A.H.M. and Aly M.M. (2013) The synergistic effects of using turmeric with some antioxidant on growth, vine nutritional status and productivity of Ruby seedless grapevines. Hortscience Journal of Suez Canal University, 1, 305-308.

Ahmed, F.F., Mansour A.E.M., Montasser M.A.A., Merwad M.A. and Mostafa E.A.M.(2013) Response of Valencia orange trees to foliar application of roselle, turmeric and seaweed extracts. J. of Applied Sci. Res., 9 (1), 960-964.

Ahmed, F.F. and Morsy, M.H. (1999) A new method for measuring leaf area in different fruit species. Minia. J. Agric. Rec. Dev., 19, 97-105.

Armanious, M.K.U. (2014) The synergistic effect of spraying some plant extracts with some macro and micro nutrients of Thompson seedless grapevines. Inter. J. Plant Soil Sci., 3, 1290-1301.

Association of Official Agricultural Chemists (1995) Official Methods of Analysis (A.O.A.C), $12^{\text {th }}$ ed. Benjamin Franklin Station, Washington D.C. U.S.A. pp. $490-510$.

Carr, M. F., Klots, J. and Bergeron, M. (2004) Coumadin resistance and the vitamin supplement "Noni”. Am. J. Hematology, 77, 103- 107.

Chapman, H.D. and Pratt P.F. (1965) Methods of Analysis of Soils, Plant and Water. Calif Univ Division of Agric. Sci., pp.: 172-173.

Chowdhury, M.N.A., Rahim M.A., Khalequzzama K.M., Humauan M. and Alan M.M. (2007) Effect of plant extracts and time of application on incidence of anthracnose, yield and quality of mango. Int. $J$. Sustain. Crop. Prod., 2 (5), 59-68.

Culver, M., Fanuel, T. and Chiteka, A.Z. (2012) Effect of moringa extract on growth and yield of tomato Greener J. Agri. Sci., 2207-211.

Egyption Ministry of Agriculture Statistics (2014) Statistics and Economic Affairs Sector, Ministry of Agric. and Land Reclamation, Egypt.

Flanders, A. and Abdulkarim S.M. (1995) The composition of seed oil of Tramira Eruca sativa. JAOCS. 62 (7), 1134- 1135.

Gad El-Kareem, M.R. and Abd El- Rahman, M.A. (2013) Response of Ruby seedless grapevines to foliar application of seaweed extract, salicylic acid and roselle extract. Hort. Sci. J. Suez Canal Univ., 1, 299-303.

Mahmoud, M.R. (2014). Impact of spraying extracts of fenugreek and rocket seed Sprouts on fruiting of Keitte mango trees. World Rural Observations, 6 (4), 75-80. 
Mead, R., Currow, R.N. and Harted, A.M. (1993) Statistical Methods in Agricultural and Experimental Biology, $2^{\text {nd }}$ ed. Chapman \& Hall London. pp 10 - 44.

Srivastava, A.K. and Lal, B. (1997) Studies on biofunicidal properties of leaf extract of some plants. Indian Phy. To Path., 3, 408-411.
Weaver, R.J. (1976) Grape growing. Wiley-Interscience Publication, New York.

Wilde, S.A., Corey R.B., Layer J.G. and Voigt, G.K. (1985) Soils and Plant Analysis for Tree Culture, Oxford and IPH publishing Co. New Delhi, India, pp.: 529- 546.

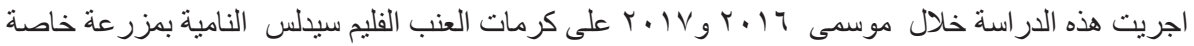

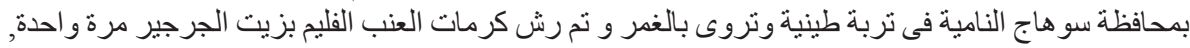

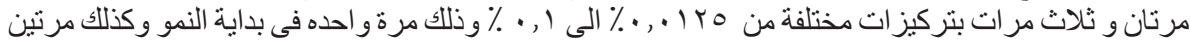
فى بداية النمو وقبل الاز هار وثثلاث مر ات في بدايه النمو وقبل الاز هار وبن وبعد العقد مباشرة.

تركزت الدراسة على اختبار تأثير الرش بمركب زيت الجرجير على النمو الخضرى وكمية المحصول

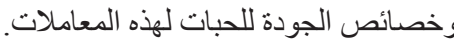

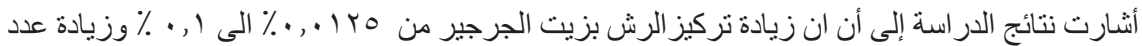

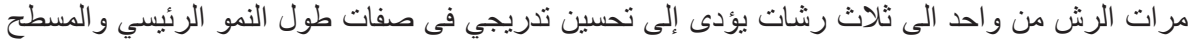

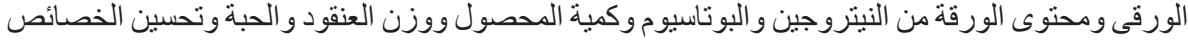
الطبيعية و الكيميائية للثمار

وكانت افضل نتيجة باستخدام التركيز ا ر ، • و والرش ثناث مر ات في بداية النمو وقبل الاز هار وبعد العقد

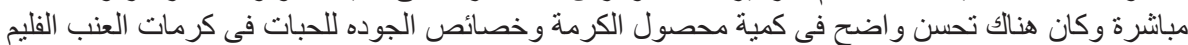

